\title{
Türkiye'de ve Dünyada Yiyecek İçecek Sektörüne Yönelik Eğitim Veren Lisans Programlarının Kıyaslanması
}

\section{The Comparison of Undergraduate Programmes Which Train Oriented to Food and Beverage Sector in Turkey and the World}

Ümit Çarbuğa a, Emel Memiş Kocaman ${ }^{\text {b* }}$

a Arş. Gör., Çanakkale Onsekiz Mart Üniversitesi, Turizm Fakültesi, Gastronomi ve Mutfak Sanatları Bölümü, Çanakkale/Türkiye ORCID: 0000-0003-0077-7410

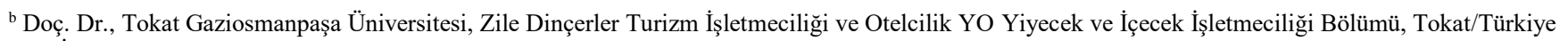
ORCID: 0000-0003-4577-3421

\section{MAKALE BİLGİSİ \\ Makale Geçmişi: \\ Başvuru tarihi: 27 Eylül 2018 \\ Düzeltme tarihi: 18 Ekim 2018 \\ Kabul tarihi: 30 Ekim 2018}

\section{Anahtar Kelimeler:}

Gastronomi

Yiyecek ve İçecek

Eğitim

Mesleki Eğitim

\section{A R T I C LE INFO}

Article history:

Received 27 September 2018

Received in revised form 18 October 2018

Accepted 30 October 2018

\section{Keywords:}

Gastronomy

Food and Beverage

Education

Vocational Education
ÖZ

Bu çalışmada; Türkiye'de ve dünyada yiyecek içecek sektörüne yönelik eğitim veren lisans programlarının isimleri ve bünyesinde bulundukları fakülte/yüksekokul bakımından ortak ve farklı yönlerinin tespit edilmesi amaçlanmıştır. $\mathrm{Bu}$ amaçla, Türkiye'deki üniversitelerin tamamı taranmıştır. Yurtdışından 8 ülkede (İspanya, İtalya, İngiltere, ABD, İsviçre, İsveç, Japonya ve Avustralya) rastgele seçilen 149 üniversitenin web siteleri incelenmiştir. Türkiye'de yiyecek içecek sektörüne yönelik lisans eğitimi veren 50 programdan \%82.0'1nın "gastronomi ve mutfak sanatları" ismini taşıdığı belirlenmiştir. Programlardan \%38.0'1nın turizm fakülteleri bünyesinde bulundukları görülmüştür. Yurtdışında araştırma kapsamına alınan ülkelerden 6'sında ilgili lisans programları tespit edilmiştir. İlgili programların bulunduğu üniversitelerde program isimlerinin; en fazla "mutfak sanatları" ile "gastronomik bilimler" olduğu tespit edilmiştir. Türkiye'de ve diğer ülkelerde bu alanda eğitim veren programlar ile bünyesinde bulundukları fakülte/yüksekokulların geniş bir isim çeşitliliğine sahip olduğu sonucuna varılmıştır.

\begin{abstract}
A B S T R A C T
In this study; it has been aimed that identifying the names of undergraduate programmes which train oriented to food and beverage sector in Turkey and in the world and their mutual and different sides in regards to the faculty/college which they are within. For this purpose, all of the universities in Turkey has been scanned. From 8 countries abroad, (Spain, Italy, England, USA, Switzerland, Sweden) websites of randomly selected 149 universities has been examined. It has been seen that, $82.0 \%$ of 50 programmes which train oriented to food and beverage sector in Turkey bear the name of "gastronomy and culinary arts". It has been seen that $38.0 \%$ of the programmes are within the tourism faculties. In 6 of the countries that are aboard taken in the scope of the research, it has been detected that there are related undergraduate programmes. It has been detected that programme names are "culinary arts" and "gastronomical science" at furthest, in the universities where there are related programmes. As a result of research findings it can be said that there is a significant variety in terms of the programmes names and faculty and colleges which the programmes are within.
\end{abstract}

\section{Giriş}

Beslenme, kuşkusuz insan hayatının devamı için en önemli gereksinimlerden biridir. Bu ihtiyacı karşılama zorunluluğu avlayıc1-toplacı dönemden bu yana pişirme, saklama, evcilleştirme, üretme, ticaret yapma ve sanata dönüştürme noktasına kadar getirmiştir (Pitte, 2002; Kurnaz, 2011).

\footnotetext{
* Sorumlu yazar/Corresponding author.

e-posta: emel.memis@gop.edu.tr
}

Yemek pişirme işi de tarihin derinliklerinde insanlığa ait ilk izlerin görüldüğü Mezopotamya'da insanlıkla birlikte ortaya çıkmış ve daha sonra Çin, Japon, Mısır, Türk, Yunan, Roma, Fransız ve İngiliz mutfakları gelişmiştir (Hatipoğlu, 2008; Flandrin ve Montanari, 2013). 
Yiyecek ve içecek kültürünün ortaya çıkmasında ve sürdürülmesinde bazı faktörler belirleyici durumdadır; iklimlere, coğrafyalara ve dini inançlara göre yiyecek içecek kültürü değişiklikler gösterir. Bu düzlemde düşünüldüğünde bir topluluğa ya da bölgeye ait değerler, olanaklar ve deneyimler toplamı neticesinde bir yiyecek içecek kültürü veya gastronomi mirası ortaya çıkmaktadır (Santich, 2004; Harrington, 2005; Beşirli, 2010). İster mutfak kültürü olarak ister gastronomi mirası olarak isimlendirilsin; birikimin ortaya çıkmasında göçler, coğrafi konumlar, dinler ve etnik kimlik oldukça etkili olmuştur. Saklama metotları, pişirme teknikleri ve tüketim biçimlerine kültürel etkileşim, bilgi ve deneyim birikimi yön vermiştir (Dördüncü, 2015).

Gastronomi kavramı; etimolojik bakımdan; Yunanca gaster (mide) ve nomas (yasa) kelimelerinin birleşmesiyle oluşmuştur (Altınel, 2009). Etimolojik yapısından öte günümüzde daha çok 'sağliğa uygun, iyi düzenlenmiş, hoşve lezzetli mutfak, yemek düzeni ve sistemi' olarak tanımlanmaktadır (TDK, 2017). Bu alandaki mevcut bilgi birikiminin oluşmasında bazı bilim dallarının katkıları söz konusudur. Gastronominin fizik, kimya, biyoloji, psikoloji ve sosyoloji gibi bilim alanlarından faydalandığ belirtilmektedir (Santich, 2007). Yine bu birikim içerisinde sanatsallık da önemli yer tutmaktadır. Gastronominin sanatsal yönü estetik ve yaratıcılık unsurlarının hazırlama ve sunum aşamalarında ortaya çıkması ile açıklanmaktadır. Bir eylemin sanat olabilmesi için hitap ettiği duyu kanalları baz alındığında; müzik kulağa ve resim göze hitap ederken, gastronomi hem göze hem de tat alma duyusuna hitap etmektedir (Huisman, 1992).

Dünya üzerinde yiyecek ve içecek unsurları düzenli olarak değişimler geçirmişlerdir. Bir zamanlar ev dışında yiyecek içecek aktiviteleri sadece kervansaraylar ve hanlarda gerçekleştirilirken, bugün ise çeşitli tarz ve ekollerden (fast food, slow food, vejetaryen beslenme, yöresel mutfaklar, uluslararası mutfaklar vb.) etkilenen veya esinlenen yiyecek içecek işletmeleri daha fazla ürün zenginliğiyle yiyecek ve içecek aktivitelerine ev sahipliği yapmaktadır (Denizer, 2005;Görgülü, 2011; Keskin, 2012). Yiyecek ve içecek işletmeleri, günümüzde bulunduğu konuma bakılarak; ürünlerin ve hizmetlerin hazırlanıp sunulmasıyla misafirlerin yiyecek ve içecek ihtiyaçlarını gideren işletmeler olarak tanımlanmaktadır (Baysal ve Küçükaslan, 2009).

Yiyecek-içecek hizmetleri endüstrisinin üretim ve faaliyetlerinde yoğun bir artıştan söz edilmektedir. Artan talep ve tüketim, temelde dışarıda yemek yeme güdüsünden kaynaklanmaktadır (Tayfun ve Tokmak 2007; Özdemir, 2010). Son yıllarda günlük hayatın hızlı bir döngü içerisine girmesi ve tüketim alışkanlıklarında oluşan değişiklikler yiyecek içecek işletmelerinin tercih edilme sıklığını artırarak yeni ve tatmin edici ürün ve hizmetlerin tüketime sunulmasının önü açılmıştır. Bu durum neticesinde farklı anlayışlarla hizmet veren restoranların (moleküler gastronomi, füzyon mutfak vb.) nitelik ve nicelik bakımından gelişimi hızlanmıştır (Hatipoğlu, 2014). Bütün bu gelişmeler neticesinde gastronomi olgusu hızla gelişmiş ve dikkat çekmeye başlamıştır (Zengin, Uyarve Erkol, 2015).

Günümüzde mutfaklarda bilim ve teknoloji kullanımı da önemli ölçüde artmıştır. Mutfaklarda bilimin daha sık kullanılması, temelde fizik ve kimya kurallarının mutfaklarda uygulanması anlamına gelen 'moleküler gastronomi' hareketini ortaya çıkarmıştır (Vega ve Ubbink, 2008; Cousins, O'Gorman ve Stierand, 2010; Gillespie ve Cousins, 2012). Batı kaynaklı pişirme teknikleri ile doğu kaynaklı pişirme teknikleri ve gidaların kombinasyonundan oluşan 'füzyon mutfağı' hareketi de yeni arayışların gastronomi içerisindeki bir yansıması olarak değerlendirilmektedir (Gustafsson, 2004; Sandıkçı ve Çelik, 2007). Kullanım ve üretim aşamalarında henüz gelişmemiş olmasına rağmen tasarım aşamasındaki çalışmaları ifade eden 'dijital gastronomi' teriminin de literatüre girdiği görülmektedir. Dijital gastronomi şimdilik gastronomi alanından önemli bir etkiye sahip olmasa da geleceğin mutfak gastronomi anlayışını; yaratıcılık, mesleki, sanatsal ve teknik yönden yeniden şekillendireceği düşünülmektedir (Gustafsson, 2004; Zoran ve Coelho, 2011;Aksoy ve Üner, 2016).

Yiyecek içecek sektörünün teknik ve ekonomik açıdan gelişmesinin doğal bir sonucu olarak bu sektörde nitelikli işgücüne duyulan ihtiyaç da artmıştır. Gerek duyulan istihdamı karşılayabilecek önlisans ve lisans düzeyinde eğitim olanakları ortaya çıkmıştır. Son yıllarda lisans düzeyinde eğitim veren; yiyecek ve içecek işletmeciliği, gastronomi, gastronomi ve mutfak sanatları gibi isimlerle çeşitli fakülte ve yüksekokul bünyelerinde bulunan çok sayıda bölüm açılmıştır (Memiş Kocaman, 2015).

$\mathrm{Bu}$ çalışma Türkiye'de ve yurtdışında yiyecek içecek sektörüne yönelik eğitim veren lisans programlarının isim ve fakülte/yüksekokul bakımında benzerliklerini ve farklılıklarını ortaya koymak amacıyla yapılmıştır. Bu doğrultuda yurtiçinde ve yurtdışında bulunan programların isim ve bünyesinde bulundukları fakülte / yüksekokul çeşitlilikleri incelenmiştir.

\section{Yiyecek ve İçecek Sektörüne Yönelik Eğitim}

Yiyecek ve içecek alanında verilen eğitimin amacı; mümkün olan en iyi beslenme ile insanın korunması ve hayattan zevk almasının sağlanmasıdır. İnsan beslenmesine uygun her ürünün hazırlanması ve sunulması, hijyen kuralları ve beslenme ile ilgili sağlık temelli etkenlerin tamamı yiyecek ve içecek eğitiminin kapsamına girmektedir. Dolayısıyla bu alandaki eğitim gıdaların uygun ortamlarda saklanması, doğru metotlarla işlenmesi, estetik ve beslenme kurallarını gözeterek sunulmasını sağlamaya yöneliktir (Gustafsson, 2004; Aslan, 2010; Condrasky ve Hegler, 2010; Hegarty, 2011). Yiyecek ve içecek alanında verilen eğitimin amacı doğrultusunda bu alandaki eğitimin bazı bilim dallarından faydalanmak durumunda olduğu anlaşılmaktadır. Öyle ki yiyecek ve içecek alanı daha önceki çalışmalarda fizik, kimya, biyoloji, sosyoloji, hukuk, ekonomi, psikoloji ve beslenme gibi bilim dalları ile yakından ilişkili olarak değerlendirilmiştir (Santich, 2007). Yiyecek içecek üretimin doğal bir gerekliliği olarak gida güvenliği, hijyen / sanitasyon, gida teknolojisi, gida mevzuatı gibi unsurların da önemli yer tutması nedeniyle gıda mühendisliği disiplininin de bu alanda önemli bir yer tuttuğu görülmektedir (Hertzman ve Ackerman, 2010; Hegarty, 2011).

Tarihte bilinen ilk yemek pişirme eğitimi 1248 yılında Fransa'da Chaine Des Rottisseurs topluğu ile başlamıştır. Fransa kralı IX Louis döneminde kurulan Chaine Des Rottisseurs saray mutfağında profesyonel bir yapılanma adına aşçılık eğitimi vermekteydi (Chainedes Rotisseurs, 
2016). 1895 yılında Paris’te kurulan bu alanda eğitim vermeyi sürdüren Le Cordon Bleu bu alanda en saygın kuruluşlardan bir tanesi olarak öne çıkmaktadır (Le Cordon Bleu, 2016). Günümüzde ise oldukça komplike bir hal almış, değer kazanmış ve yaygın şekilde yiyecek içecek eğitimi pek çok kurum tarafından farklı düzeylerde sürdürülmektedir (Pavesic, 1993; Hegarty, 2005; Hertzman ve Ackerman, 2010).

Edelstein'e (2008) göre mutfak ve yiyecek içecek yöneticilerinin uzman olması; iş bilgisi, ekipman planlama, pazarlama, ekonomik planlama, düzenleyici bilgi, kaynak yönetimi, yönetim ve liderlik, beslenme bilgisi, yemek pişirme ve yemek bilgisi, gıda güvenliği, kalite kontrol, hasar planlama, müşteri servisi, bilgisayar yetenekleri, personel yetiştirme yetenekleri olarak sıralanmaktadır. Edelstein (2008) tarafindan ortaya koyulan model Şekil 1'de görülmektedir.

Son yıllarda yiyecek içecek alanıyla ilgili eğitimi inceleyen çalışmalar yapılmaktadır. Sevim ve Görkem'in (2015) yaptığ 1 araştırmaya göre, gastronomi, aşçılık, gastronomi ve mutfak sanatları, mutfak sanatları ve yönetimi eğitimi alanların fiziksel yeterliliğe sahip olmayan ve hijyen kurallarına gerekli özenin gösterilmediği ortamlarda eğitim aldıkları belirtilmiştir. Ayrıca bu alanda eğitim almış ve almakta olan kişilerin özellikle çapraz bulaşma ve 1S1 kontrolü gibi konularda yeterli bilgi düzeylerine sahip olmadığı tespit edilmiştir. Bir başka araştırmada ise yiyecek ve içecek işletmeciliği öğrencilerinin gida güvenliği bilgisi kontrol grubuna kıyasla önemli düzeyde yüksek bulunmuştur (Memiş Kocaman, 2015). Türkiye'de düzenlenen "1. Gastronomi Eğitimi Arama Konferansı" da bu çalışmalardan birisidir. Konferansta programların genel yapısı üzerinden analizler yapılmıştır. Verilmekte olan eğitiminin niteliği, akademisyenlerin mesleki donanımı, yeterli ekipman ve uygulama alanı temini, uygulamalı derslerin yetersizliği ve toplam ders sayıları konusunda tespit ve öneriler sunulmuştur. Genel olarak gastronomi alanında verilen eğitimin eksikleri vurgulanırken; müfredatların uygulamalı ağırlıklı yeniden düzenlenmesi, gerekli akademik personelin sağlanması ve program isimlerinin düzenlenmesi başlıca önerilerdendir (Kozak ve Açıköz, 2015).

Türkiye'de ve yurtdışında yiyecek içecek sektörüne yönelik eğitim veren program amaçlarının program ismi bakımından benzerlik ve farklılıklarının anlaşılması adına farklı isimler taşıyan programların (gastronomi ve mutfak sanatları, yiyecek ve içecek işletmeciliği, gastronomik bilimler, gastronomi) eğitim amaçlarına göz atmak gerekmektedir. Nişantaşı Üniversitesi gastronomi ve mutfak sanatları programı ile ilgili bilgi metninde; yiyecek ve içecek sektöründe istihdam edilecek akademik ve analitik kabiliyetlere sahip mezunlar vermeyi amaçladığı vurgulamaktadır (Nişantaşı Üniversitesi, 2016). Gaziosmanpaşa Üniversitesi yiyecek ve içecek işletmeciliği bölümü tanıtım metninde programın amacı 'yiyecek içecek sektöründe sorumluluk alabilecek ve kendi işletmesini yönetebilecek işgücü yetiştirmek' olarak belirtilmektedir (Gaziosmanpaşa Üniversitesi, 2016). İtalya'da bulunan Gastronomik Bilimler Üniversitesi gastronomi programı misyonu 'geliştirilmiş mutfak yeteneklerine sahip, gıda güvenliği ve gıda sanatı konusunda bilgili, dünya lezzetlerine hakim şefler yetiştirmek' şeklinde belirtilmiştir
(Universita degli studi di Scienze Gastronomiche, 2017). İspanya'da eğitim veren Valencia Üniversitesi gastronomik bilimler programı misyonu ise 'yüksek ekonomik değere sahip gastronomi alanında yöneticilik, yenilikçilik ve yaratıcılık kabiliyetlerine sahip, gastronomi projeleri hazırlayıp yürütebilecek profesyoneller yetiştirmek' olarak belirlenmiştir (Universitat de Valencia,2017). Örneklerde de görüldüğü gibi, farklı isimler taşıyan programların tanıtım metinlerinde benzer ifadeler yer almakta ve genel itibari ile ortak amacın 'yiyecek ve içecek sektörüne donanımlı yöneticiler / şefler yetiştirmek olduğu anlaşılmaktadır.

Şekil 1. Mutfak ve Yiyecek İçecek Servisi Yöneticilerinin Uzman Olması Gereken Alanlar

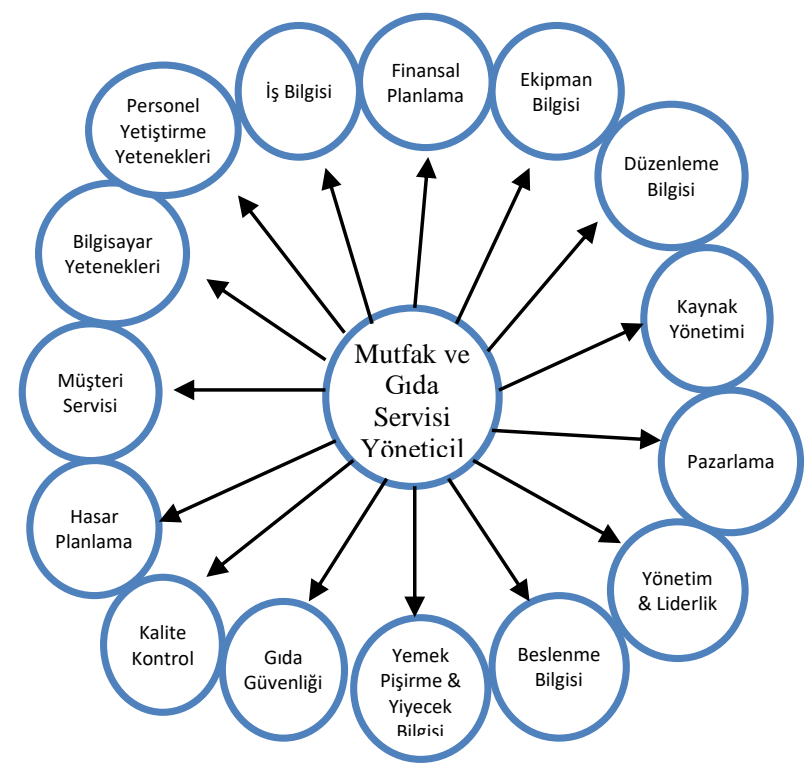

Kaynak: Edelstein (2008)

\section{Yöntem}

$\mathrm{Bu}$ çalışmada nitel araştırma yöntemlerinden birisi olan tarama yöntemi kullanılmıştır. Yerli ve yabancı üniversitelerin bünyelerinde bulunan gastronomi, gastronomi ve mutfak sanatları, gastronomik bilimler, yiyecek ve içecek işletmeciliği, mutfak sanatları ve yönetimi programları resmi internet siteleri aracılığıyla tespit edilmiştir. Belirlenen programların bünyesinde bulunduğu fakülte / yüksekokula ilişkin bilgiler elde edilmiştir. $\mathrm{Bu}$ bilgiler üzerinden, yiyecek ve içecek sektörüne yönelik lisans eğitimi veren programların benzerlik ve farklılıkları değerlendirilmiştir.

Çalışmada cevap verilmeye çalışılan sorular şu şekildedir:

(i) Türkiye'de ve dünyada bulunan yiyecek içecek sektörüne yönelik eğitim veren lisans programları isimleri bakımından farklılık göstermekte midir?

(ii) Programların bünyesinde bulunduğu fakülte / yüksekokul farklılık göstermekte midir?

Bu soruların cevabına ulaşmak üzere Türkiye'de bulunan programların tespiti için ÖSYM (2017) tarafindan yayınlanan Öğrenci Seçme ve Yerleştirme Sistemi (ÖSYS) Yükseköğretim Programları ve Kontenjanları Kılavuzu kayıtları kullanılmıştır. Yurtdışında bulunan programların tespiti için de internet üzerinden tarama yapılmıştır. Yapılan taramada 8 farklı ülkede bulunan 149 üniversitenin internet 
siteleri ziyaret edilmiştir. Bunlar içerisinde 6 farklı ülkeden 13 üniversitenin ilgili programlarına ait bilgilere ulaşılmış ve araştırma kapsamına alınmıştır. Elde edilen veriler değerlendirilerek, tablolar halinde sunulmuştur.

\section{Bulgular}

Türkiye'de yiyecek ve içecek sektörüne yönelik lisans düzeyinde eğitim veren programlar Tablo 1'de gösterilmiştir.

Tablo 1'de görülen programlar ÖSYM tarafindan 2017 yılında yayınlanan ÖSYS Yükseköğretim Programları ve
Kontenjanları Kılavuzuna dayalı olarak tespit edilmiştir. Türkiye'de yiyecek ve içecek sektörüne yönelik eğitim verilen lisans programları gastronomi, gastronomi ve mutfak sanatları, yiyecek ve içecek işletmeciliği, mutfak sanatları ve yönetimi isimleri ile çeşitli üniversitelerin bünyesinde yer almaktadır. $\mathrm{Bu}$ programların içerisinde bulundukları fakülte/yüksekokullar da farklılıklar göstermektedir. İlgili programların; turizm ve otelcilik yüksekokulu, turizm fakültesi, uygulamalı bilimler yüksekokulu, turizm işletmeciliği ve otelcilik yüksekokulu, güzel sanatlar fakültesi, sanat ve tasarım fakültesi bünyesinde bulunabildiği belirlenmiştir (ÖSYM, 2017).

Tablo 1: Türkiye'de Yiyecek ve İçecek Sektörüne Yönelik Lisans Eğitimi Veren Programlar

\begin{tabular}{|c|c|c|c|}
\hline Sira No & Üniversite & Fakülte/Yüksekokul & Program İsmi \\
\hline 1 & Abant İzzet Baysal Ün. & Turizm İşletmeciliği ve Otelcilik YO. & Gastronomi ve Mutf. Sanatları \\
\hline 2 & Adnan Menderes Ün. & Turizm Fakültesi & Yiyecek ve İçecek İşletmeciliği \\
\hline 3 & Afyon Kocatepe Ün. & Turizm Fakültesi & Gastronomi ve Mutf. Sanatları \\
\hline 4 & Akdeniz Ün. & Turizm Fakültesi & Gastronomi ve Mutf. Sanatları \\
\hline 5 & Akdeniz Ün. & Turizm Fakültesi (Manavgat) & Gastronomi ve Mutf. Sanatları \\
\hline 6 & Alanya Alaaddin Key. Ün. & Turizm Fakültesi & Gastronomi ve Mutf. Sanatları \\
\hline 7 & Alanya Hamdullah Paşa Ün. & Turizm Fakültesi & Gastronomi ve Mutf. Sanatları \\
\hline 9 & Anadolu Ün. & Turizm Fakültesi & Gastronomi ve Mutf. Sanatları \\
\hline 10 & Antalya AKEV Ün. & Sanat ve Tasarım Fakültesi & Gastronomi ve Mutf. Sanatları \\
\hline 11 & Antalya Bilim Ün. & Turizm Fakültesi & Gastronomi ve Mutf. Sanatları \\
\hline 12 & Atatürk Ün. & Turizm Fakültesi & Gastronomi ve Mutf. Sanatları \\
\hline 13 & Avrasya Ün. & Uygulamalı Bilimler YO. & Gastronomi ve Mutf. Sanatları \\
\hline 14 & Bahçeşehir Ün. & Uygulamalı Bilimler YO. & Gastronomi \\
\hline 15 & Balıkesir Ün. & Turizm Fakültesi & Gastronomi ve Mutf. Sanatları \\
\hline 17 & Beykent Ün. & Uygulamalı Bilimler YO. & Gastronomi ve Mutf. Sanatları \\
\hline 18 & Cumhuriyet Ün. & Turizm İşletmeciliği ve Otelcilik YO. & Gastronomi ve Mutf. Sanatları \\
\hline 19 & Çanakkale Onsekiz Mart Ün. & Uygulamalı Bilimler YO. & Gastronomi ve Mutf. Sanatları \\
\hline 20 & Doğuş Ün. & Sanat ve Tasarım Fakültesi & Gastronomi ve Mutf. Sanatları \\
\hline 21 & Dokuz Eylül Ün. & Uygulamalı Bilimler YO. & Gastronomi ve Mutf. Sanatları \\
\hline 22 & Gazi Ün. & Turizm Fakültesi & Gastronomi ve Mutf. Sanatları \\
\hline 23 & Gaziantep Ün. & Güzel Sanatlar Fakültesi & Gastronomi ve Mutf. Sanatları \\
\hline 24 & Gaziosmanpaşa Ün. & Turizm İşletmeciliği ve Otelcilik YO. & Yiyecek ve İçecek İşletmeciliği \\
\hline 25 & İstanbul Aydın Ün. & Güzel Sanatlar Fakültesi & Gastronomi ve Mutf. Sanatları \\
\hline 26 & İstanbul Ayvansaray Ün. & Uygulamalı Bilimler YO. & Gastronomi ve Mutf. Sanatları \\
\hline 27 & İstanbul Bilgi Ün. & Turizm İşletmeciliği ve Otelcilik YO. & Gastronomi ve Mutf. Sanatları \\
\hline 28 & İstanbul Gelişim Ün. & Güzel Sanatlar Fakültesi & Gastronomi ve Mutf. Sanatları \\
\hline 29 & İstanbul Gelişim Ün. & Uygulamalı Bilimler YO. & Gastronomi \\
\hline 30 & İstanbul Medeniyet Ün. & Turizm Fakültesi & Gastronomi ve Mutf. Sanatları \\
\hline 31 & İstanbul Medipol Ün. & Güzel Sanatlar Tasarım ve Mim. Fak. & Gastronomi ve Mutf. Sanatları \\
\hline 34 & İzmir Katip Çelebi Ün. & Turizm Fakültesi & Gastronomi ve Mutf. Sanatları \\
\hline 35 & Kocaeli Ün. & Turizm İşletmeciliği ve Otelcilik YO. & Gastronomi ve Mutf. Sanatları \\
\hline 36 & Maltepe Ün. & Güzel Sanatlar Fakültesi & Gastronomi ve Mutf. Sanatları \\
\hline 37 & Mardin Artuklu Ün. & Turizm İşletmeciliği ve Otelcilik YO. & Gastronomi ve Mutf. Sanatları \\
\hline 38 & Mehmet Akif Ersoy Ün. & Turizm İşletmeciliği ve Otelcilik YO. & Gastronomi ve Mutf. Sanatları \\
\hline 39 & Mersin Ün. & Turizm Fakültesi & Gastronomi ve Mutf. Sanatları \\
\hline 40 & Muğla Sitkı Koçman Ün. & Turizm Fakültesi & Yiyecek ve İçecek İşletmeciliği \\
\hline 41 & Necmettin Erbakan Ün. & Turizm Fakültesi & Gastronomi ve Mutf. Sanatları \\
\hline 42 & Nevşehir Hacı Bektaş Veli Ün. & Turizm Fakültesi & Gastronomi ve Mutf. Sanatları \\
\hline 43 & Nişantaş1 Ün. & Sanat ve Tasarım Fakültesi & Gastronomi ve Mutf. Sanatları \\
\hline 44 & Okan Ün. & Uygulamalı Bilimler YO. & Gastronomi \\
\hline 45 & Özyeğin Ün. & Uygulamalı Bilimler YO. & Gastronomi ve Mutf. Sanatları \\
\hline 46 & Pamukkale Ün. & Turizm Fakültesi & Gastronomi ve Mutf. Sanatları \\
\hline 47 & Selçuk Ün. & Turizm Fakültesi & Gastronomi ve Mutf. Sanatları \\
\hline 48 & Sinop Ün. & Turizm İşletmeciliği ve Otelcilik YO. & Yiyecek ve İçecek İşletmeciliği \\
\hline 49 & Yaşar Ün. & Uygulamalı Bilimler YO. & Gastronomi ve Mutf. Sanatları \\
\hline 50 & Yeditepe Ün. & Güzel Sanatlar Fakültesi & Gastronomi ve Mutf. Sanatları \\
\hline
\end{tabular}


Türkiye'de yiyecek ve içecek sektörüne yönelik lisans düzeyinde eğitim veren programların isimlerine göre dağılımı Tablo 2'de gösterilmiştir.

Tablo 2. Türkiye'de Bulunan Programların İsimlerine Göre Dağılımı

\begin{tabular}{lcc}
\hline Program ismi & $\mathrm{N}$ & $\%$ \\
\hline Gastronomi ve Mutfak Sanatları & 41 & 82.0 \\
Yiyecek ve İçecek İşletmeciliği & 4 & 8.0 \\
Gastronomi & 4 & 8.0 \\
Mutfak Sanatları ve Yönetimi & 1 & 2.0 \\
\hline Toplam & 50 & 100.0 \\
\hline
\end{tabular}

Tablo 2'de görüldüğü gibi, Türkiye'de yiyecek içecek sektörüne yönelik eğitim veren programlar arasında en fazla rastlanan ismin Gastronomi ve Mutfak Sanatları olduğu saptanmıştır (\%82.0). Programlardan 4'ünün Yiyecek ve İçecek İșletmeciliği (\%8.0), 4'ünün Gastronomi (\%8.0) ve sadece 1'inin Mutfak Sanatları ve Yönetimi ismini taşıdığ (\%2.0) belirlenmiştir.

Tablo 3'te Türkiye'de yiyecek ve içecek sektörüne yönelik eğitim veren programların fakülte / yüksekokullara göre dağılımı görülmektedir. Programların en fazla turizm fakülteleri içerisinde bulunduğu saptanmıştır (\%38.0). Diğerlerinin sırasıyla uygulamalı bilimler yüksek okulları (\%24.0), turizm işletmeciliği ve otelcilik yüksekokulları (\%16.0), güzel sanatlar fakülteleri (\%10.0), sanat ve tasarım fakülteleri $(\% 8.0)$ ile güzel sanatlar tasarım ve mimarlık fakülteleri (\%4.0) bünyelerinde bulundukları belirlenmiştir.

Tablo 3. Türkiye'de Bulunan Programların Bünyesinde Bulunduğu Fakülteye/Yüksekokula Göre Dağılımı

\begin{tabular}{lcc}
\hline Fakülte/Yüksekokul & $\mathrm{N}$ & $\%$ \\
\hline Turizm Fakültesi & 19 & 38.0 \\
Uygulamalı Bilimler Yüksekokulu & 12 & 24.0 \\
Turizm İşletmeciliği ve Otelcilik Yüksekokulu & 8 & 16.0 \\
Güzel Sanatlar Fakültesi & 5 & 10.0 \\
Sanat ve Tasarım Fakültesi & 4 & 8.0 \\
Güzel Sanatlar Tasarım ve Mimarlık Fakültesi & 2 & 4.0 \\
\hline Toplam & 50 & 100.0 \\
\hline
\end{tabular}

Yurtdışından 8 ülkenin üniversiteleri bünyesinde yiyecek ve içecek sektörüne yönelik eğitim veren lisans programları taranmış, bulunan programlar ülkeleri ve bünyesinde bulundukları üniversite ile birlikte Tablo 4 'te verilmiştir.

Toplamda 8 farklı ülkede bulunan 149 üniversitenin internet siteleri ziyaret edilmiş, 6 farklı ülkeden 13 üniversitenin ilgili programları bünyelerinde bulundurdukları anlaşılmıştır. $\mathrm{ABD}$ de bulunan 22 üniversitenin resmi internet siteleri ziyaret edilmiş ve bu üniversitelerden 4 tanesinin araştırmaya konu olan programları bünyesinde bulundurdukları tespit edilmiştir. İngiltere'de bulunan 20 üniversitenin resmi internet siteleri ziyaret edilerek toplam 2 üniversite ilgili programın bulunduğu anlaşılmıştır. İspanya'da bulunan 20 üniversitenin resmi internet sitelerinin taranması sonucunda 3 üniversitenin söz konusu programları bünyelerinde bulundurdukları anlaşılmıştır. İtalya'da bulunan üniversitelerden 20 'sinin resmi internet siteleri ziyaret edilmiş ve bunlardan 2'sinde araştırma kapsamındaki programa rastlanmış, bunlardan birinin 'Gastronomik Bilimler Üniversitesi' ismini taşıyan bir üniversite olduğu tespit edilmiştir. Birçok ülkede bu alanda verilen eğitim için lisans programları bulunurken İtalya'da bir üniversite kurulmuş olması dikkat çekici bulunmuştur.
İsveç'te bulunan üniversitelerden 14'ünün resmi internet siteleri ziyaret edilmiş ve bunlardan yalnızca birinin ilgili programı bünyesinde bulundurduğu görülmüştür. İsviçre'de 12 farklı üniversitenin resmi internet sitesi ziyaret edilmiş ve bu üniversitelerden sadece bir tanesinde ilgili program tespit edilmiştir. Japonya'da bulunan 21 üniversitenin ve Avustralya' da bulunan 20 üniversitenin remi internet siteleri ziyaret edilmiş ancak bu üniversiteler bünyesinde ilgili programlara rastlanmamıştır.

Tablo 4. Yurtdışında Yiyecek ve İçecek Sektörüne Yönelik Eğitim Veren Lisans Programları

\begin{tabular}{|c|c|c|c|}
\hline Ülke & Üniversite & Fakülte/Yüksekokul & Program \\
\hline ABD & $\begin{array}{l}\text { Cornell } \\
\text { Üniversitesi }\end{array}$ & $\begin{array}{l}\text { SC Johnson İşletme } \\
\text { Enstitüsü }\end{array}$ & $\begin{array}{l}\text { Yiyecek ve } \\
\text { İçecek } \\
\text { İşletmeciliği }\end{array}$ \\
\hline $\mathrm{ABD}$ & $\begin{array}{l}\text { Drexel } \\
\text { Üniversitesi }\end{array}$ & $\begin{array}{l}\text { G1da ve Ağırlama } \\
\text { İşletmeciliği } \\
\text { Merkezi }\end{array}$ & $\begin{array}{l}\text { Mutfak } \\
\text { Sanatları ve } \\
\text { Bilimi } \\
\end{array}$ \\
\hline $\mathrm{ABD}$ & $\begin{array}{l}\text { Johnson\&Wales } \\
\text { Üniversitesi }\end{array}$ & $\begin{array}{l}\text { Mutfak Sanatları } \\
\text { Yüksekokulu }\end{array}$ & $\begin{array}{l}\text { Mutfak } \\
\text { Sanatları }\end{array}$ \\
\hline $\mathrm{ABD}$ & $\begin{array}{l}\text { Boston } \\
\text { Üniversitesi }\end{array}$ & Gıda Yüksekokulu & $\begin{array}{l}\text { Mutfak } \\
\text { Sanatları }\end{array}$ \\
\hline İngiltere & $\begin{array}{l}\text { Birmingham } \\
\text { Üniversitesi }\end{array}$ & Gıda Yüksekokulu & $\begin{array}{l}\text { Mutfak } \\
\text { Sanatları }\end{array}$ \\
\hline İngiltere & $\begin{array}{l}\text { Bat1 Londra } \\
\text { Üniversitesi }\end{array}$ & $\begin{array}{l}\text { Turizm ve } \\
\text { Ağırlama } \\
\text { Yüksekokulu }\end{array}$ & $\begin{array}{l}\text { Mutfak } \\
\text { Sanatları } \\
\text { Yönetimi } \\
\end{array}$ \\
\hline İspanya & $\begin{array}{l}\text { Valencia } \\
\text { Üniversitesi }\end{array}$ & Eczacılık Fakültesi & $\begin{array}{l}\text { Gastronomik } \\
\text { Bilimler }\end{array}$ \\
\hline İspanya & $\begin{array}{l}\text { Mondragon } \\
\text { Üniversitesi }\end{array}$ & $\begin{array}{l}\text { Gastronomik } \\
\text { Bilimler Fakültesi }\end{array}$ & $\begin{array}{l}\text { Gastronomi ve } \\
\text { Mutfak } \\
\text { Sanatları }\end{array}$ \\
\hline İspanya & $\begin{array}{l}\text { Ceu Cardinal } \\
\text { Herrera } \\
\text { Üniversitesi } \\
\end{array}$ & $\begin{array}{l}\text { Gastronomi \& } \\
\text { Mutfak Sanatları } \\
\text { Yüksekokulu } \\
\end{array}$ & Gastronomi \\
\hline İtalya & $\begin{array}{l}\text { Parma } \\
\text { Üniversitesi }\end{array}$ & $\begin{array}{l}\text { Gıda ve İlaç } \\
\text { Fakültesi }\end{array}$ & $\begin{array}{l}\text { Gastronomik } \\
\text { Bilimler }\end{array}$ \\
\hline İtalya & $\begin{array}{l}\text { Gastronomik } \\
\text { Bilimler } \\
\text { Üniversitesi } \\
\end{array}$ & $\begin{array}{l}\text { Pollenzo Aşç1lık } \\
\text { Yüksekokulu }\end{array}$ & $\begin{array}{l}\text { Gastronomi } \\
\text { Bilimleri }\end{array}$ \\
\hline İsveç & $\begin{array}{l}\text { Umea } \\
\text { Üniversitesi }\end{array}$ & $\begin{array}{l}\text { Restoran ve Mutfak } \\
\text { Sanatları Okulu } \\
\end{array}$ & $\begin{array}{l}\text { Mutfak } \\
\text { Sanatları } \\
\end{array}$ \\
\hline İsviçre & $\begin{array}{l}\text { Uluslararası } \\
\text { İşletme Enstitüsü }\end{array}$ & $\begin{array}{l}\text { Uluslararası Mutfak } \\
\text { Enstitüsü }\end{array}$ & $\begin{array}{l}\text { Uluslararas1 } \\
\text { Mutfak } \\
\text { Sanatları }\end{array}$ \\
\hline
\end{tabular}

Yurtdışında yiyecek ve içecek sektörüne yönelik lisans düzeyinde eğitim veren programların isimlerine göre dağılımı Tablo 5'de gösterilmiştir.

Tablo 5. Yurtdışında Bulunan Programların İsimlerine Göre Dağılımı

\begin{tabular}{lcc}
\hline Program ismi & $\mathrm{N}$ & $\%$ \\
\hline Mutfak Sanatları & 4 & 30.8 \\
Gastronomik Bilimler & 3 & 23.0 \\
Mutfak Sanatları ve Bilimi & 1 & 7.7 \\
Mutfak Sanatları Yönetimi & 1 & 7.7 \\
Uluslararası Mutfak Sanatları & 1 & 7.7 \\
Gastronomi ve Mutfak Sanatları & 1 & 7.7 \\
Yiyecek ve İçecek İşletmeciliği & 1 & 7.7 \\
Gastronomi & 1 & 7.7 \\
\hline Toplam & 13 & 100.0 \\
\hline
\end{tabular}

Tablo 5'de görüldüğü gibi, yurtdışında yiyecek içecek sektörüne yönelik eğitim veren programlar arasında en fazla 
rastlanan ismin Mutfak Sanatları olduğu saptanmıştır (\%30.8). Programlardan 4'ünün de "mutfak sanatları" ismini; mutfak sanatları ve bilimi, mutfak sanatları yönetimi, uluslararası mutfak sanatları, gastronomi ve mutfak sanatları şeklinde kullandıkları tespit edilmiştir. Gastronomik Bilimler ismi (1 tanesi gastronomi bilimleri) (\%23.0) tekrar eden program ismi bakımından 2. sırada yer almıştır. Birer program da yiyecek ve içecek işletmeciliği ile gastronomi ismiyle belirlenmiştir.

\section{Sonuç ve Öneriler}

Bu çalışmada, Türkiye'de ve yurt dışında yiyecek içecek sektörüne yönelik lisans eğitimi veren programların isimleri ve bünyesinde bulundukları fakülte / yüksekokullar bakımından farklılıkların ortaya çıkarılarak, bu durumun değerlendirilmesi amaçlanmaktadır

Türkiye'de bulunan programların bünyesinde bulunduğu fakülte / yüksekokul bakımından farklılıkların olduğu görülmüş̧tür. Toplamda 50 programdan 19'unun (\%38.0) turizm fakülteleri, 12'sinin (\%24.0) uygulamalı bilimler yüksek okulları, 8'inin (\%16.0) turizm işletmeciliği ve otelcilik yüksekokulları, 5'inin (\%10.0) güzel sanatlar fakülteleri, 4'ünün (\%8.0) sanat tasarım fakülteleri, 2'sinin (\%4.0) de güzel sanatlar tasarım ve mimarlık fakülteleri bünyesinde bulundukları belirlenmiştir. Yine Türkiye'de bulunan programların isimleri bakımından da bir çeşitliliğin olduğu anlaşılmıştır. Programlar arasında en fazla rastlanan ismin gastronomi ve mutfak sanatları olduğu, 41 (\%82.0) programın bu ismi taşıdığı anlaşılmıştır. Diğer programların yiyecek ve içecek işletmeciliği, gastronomi ile mutfak sanatları ve yönetimi isimlerini taşıdığı görülmektedir.

Yurtdışında bulunan programlarda ise "gastronomi", ve "mutfak sanatları" ifadelerinin sıklıkla birbirinden ayrı değerlendirildiği görülürken, en sık rastlanan program isminin "mutfak sanatları" olduğu anlaşılmaktadır. Mutfak sanatları programları 13 program arasında 4 kez gözlemlenirken gastronomik bilimler ismi taşıyan 3 programın olduğu tespit edilmiştir. Programlardan 4'ünün de "mutfak sanatları" ismini; mutfak sanatları ve bilimi, mutfak sanatları yönetimi, uluslararası mutfak sanatları, gastronomi ve mutfak sanatları şeklinde kullandıkları tespit edilmiştir. $\mathrm{Bu}$ noktada; yurtdışında bulunan üniversiteler genel olarak gastronomi ile mutfak sanatları olgularını ayr1 ayrı değerlendirmektedir. Türkiye'de ise bu iki olgunun bir araya getirilerek tek bir program oluşturulduğu görülmektedir. Ancak bu durumun Türkiye ile birlikte İspanya'da da bir örneğinin bulunduğu anlaşılmaktadır. İspanya'da bulunan Mondragon Üniversitesi Gastronomik Bilimler Fakültesi bünyesinde yer alan gastronomi ve mutfak sanatları programı Türkiye'de olduğu gibi gastronomi ile mutfak sanatları olgularını bir araya getirmiştir. Gastronomik bilimler isimli programların sayısının 3 olduğu tespit edilirken, İtalya'da bu ismi taşıyan bir de üniversitenin bulunduğu görülmüştür. Diğer program isimlerinin ise; yiyecek ve içecek işletmeciliği, mutfak sanatları ve bilimi, mutfak sanatları yönetimi, gastronomi, uluslararası mutfak sanatları şeklinde olduğu tespit edilmişstir. Yurtdışında bulunan programların içerisinde bulundukları fakülte ve yüksekokullara bakıldığında iki istisna dışında her birinin farklı bir fakülte / yüksekokul bünyesinde bulunduğu anlaşılmıştır. ABD'de Boston Üniversitesi bünyesinde bulunan mutfak sanatları programı ile İngiltere'de
Birmingham Üniversitesi bünyesinde bulunan mutfak sanatları programları gıda yüksekokulu içerisinde yer almaktadır. Diğer tüm programlar; işletme enstitüsü, gastronomik bilimler fakültesi, aşçılık yüksekokulu, tarım, gastronomi \& mutfak sanatları yüksekokulu, turizm ve ağırlama yüksekokulu, restoran ve mutfak sanatları okulu, uluslararası mutfak enstitüsü, mutfak sanatları yüksekokulu, gıda ve ağırlama işletmeciliği merkezi, gıda ve ilaç fakültesi, eczacılık fakültesi bünyelerinde yer almaktadırlar.

Çalışmada elde edilen bulgular neticesinde yiyecek içecek sektörüne yönelik lisans eğitimi veren programlar için;

(i) Türkiye'de ve dünyada taşıdıkları isimler bakımından belirgin bir çeşitliliğin bulunduğu,

(ii) Programların bünyesinde bulundukları fakülte ve yüksekokul farklılığının varlığ 1 ,

(iii) Türkiye'de bulunan program isimlerinde yaygın olarak gastronomi ile mutfak sanatları olgularını bir arada kullanılırken, yurtdışında her iki olgunun da ayrı ele alındığı sonucuna ulaşılmıştır.

Yurtdışında bulunan programlarda öğrencilerin iş hayatına adaptasyonunu sağlamak adına müfredat dâhilinde "işe yerleştirme", çalışmasına yer verdikleri görülürken, Türkiye'de de “staj” kapsamında öğrencilerin sektörle ve iş hayatıyla tanışması sağlanmaktadır. Programdaki bazı uygulamalı derslerin iş yeri uygulaması şeklinde yürütülmesi öğrencilerin iş hayatına adaptasyonuna katkı sağlayabilir. Ayrıca sektör-üniversite işbirliği anlaşmalarının sağlanmasıyla mezun durumunda bulunan öğrencilerin istihdamı artırılabilir.

Yapılacak yeni araştırmalarda program isimleri ve programları bünyesinde bulunduran fakülte / yüksekokul farklılıklarının nedenleri ve etkilerinin araştırılması yol gösterici olabilir. $\mathrm{Bu}$ bakımdan ilgili programların müfredatları, ders saatleri, ders içerikleri de kıyaslanarak daha kapsamlı sonuçlar ortaya çıkarılabilir.

\section{Kaynakça}

Aksoy, M., \& Üner, E. H. (2016). Rafine Mutfağın Doğuşu ve Rafine Mutfağı Şekillendiren Yenilikçi Mutfak Akımlarının Yiyecek İçecek İşletmelerine Etkileri. Gazi Üniversitesi Sosyal Bilimler Dergisi, 3(6), 1-17.

Altınel, H. (2009). Gastronomide Menü Yönetimi. Yüksek Lisans Tezi. İstanbul: İstanbul Üniversitesi.

Aslan, H. (2010). Gastronomi Turizminin Turizm Eğitimi Programlarındaki Yeri ve Önemi-Bir Uygulama. Yüksek Lisans Tezi. Konya: Selçuk Üniversitesi.

Baysal, A., \& Küçükaslan, N. (2009). Beslenme Ilkeleri ve Menü Planlama. Bursa: Ekin Yayın Dağıtım.

Beşirli, H. (2010). Yemek, Kültür ve Kimlik. Milli Folklor, 22(87), 159-169.

Chaine des Rotisseurs (2016). (Erişim: 10.06.2016), http://www.chainedesrotisseurs.com/base_newmenu .php? code $=12$

Condrasky, M. D., \& Hegler, M. (2010). How Culinary Nutrition Can Save the Health of a Nation. Journal of Extension, 48(2), 1-6. 
Cousins, J., O'Gorman, K., \& Stierand, M. (2010). Molecular Gastronomy: Cuisine Innovation or Modern Day Alchemy?, International Journal of Contemporary Hospitality Management, 22(3), 399-415.

Denizer, D. (2005). Yiyecek Içecek Yönetimi. Ankara: Detay Yayıncilık.

Dördüncü, G. (2015). Yiyecek, İçecek Kültürü: Geçmiş ve Gelecek Perspektifinde Turizm ve Kimlik Olgusu. İçinde: 2. Uluslararası Turizm ve Yönetim Araştırmaları Kongresi. Kuşadası/Aydın.

Edelstein, S. F. (2008). Mananging Food and Nutrition Services. Sudbury, Massachusetts: Jones And Bartlett Publishers.

Flandrin, J. L., \& Montanari, M. (2013). Food: A Culinary History. New York: Columbia University Press.

Gaziosmanpaşa Üniversitesi (2016). Zile Dİnçerler Turizm Işletmeciliği ve Otelcilik Yüksekokulu Yiyecek ve İçecek İşletmeciliği Bölümü Tanıtım. (Erișim: 09.06.2016), http://zturizm.gop.edu.tr/bolumDefault.aspx?dilld=1\&bi rimlerId=21\&bolumlerId=150\&menuKod=unitetanitimi

Gillespie, C., \& Cousins, J. (2012). European Gastronomy into the 21st Century. New York: Routledge.

Görgülü, M. (2011). Yiyecek Içecek Sektöründe Fast Food Uygulamalarl ve Franchising Sisteminin Değerlendirilmesi. Yüksek Lisans Tezi. İzmir: Dokuz Eylül Üniversitesi.

Gustafsson, I. B. (2004). Culinary Arts and Meal Science-A New Scientific Research Discipline. Food Service Technology,4(1), 9-20.

Harrington, R. J. (2005). Defining Gastronomic Identity: The Impact of Environment and Culture an Prevailing Components, Texture and Flavors in Wine and Food. Journal of Culinary Science \& Technology, 4(2-3), 129152.

Hatipoğlu, A. (2008). Türk Mutfağının Dünya Mutfağındaki Yeri. (Erişim: 22.05.2016), http://foodinlife.com.tr/makale/122

Hatipoğlu, A. (2014). Osmanlı Saray Mutfağı'nın Gastronomi Turizmi Çerçevesinde Incelenmesi. Doktora Tezi. Sakarya: Sakarya Üniversitesi.

Hegarty, J. A. (2005). Developing "Subject Fields" in Culinary Arts, Science, and Gastronomy. Journal of Culinary Science \& Technology, 4(1), 5-13.

Hegarty, J. A. (2011). Achieving Excellence by Means of Critical Reflection and Cultural İmagination in Culinary Arts and Gastronomy Education. Journal of Culinary Science \& Technology,9(2), 55-65.

Hertzman, J., \& Ackerman, R. (2010). Evaluating Quality in Associate Degree Culinary Arts Programs. Quality Assurance in Education, 18(3), 209-226.

Huisman, D. (1992). Estetik. Cem Muhtaroğlu (Çev.) İstanbul: İletişim Yayınları.

Keskin, E. B. (2012). Sürdürülebilir Kent Kavramına Farklı Bir Bakış: Yavaş Şehirler (Cittaslow). Paradoks Ekonomi, Sosyoloji ve Politika Dergisi, 8(1), 81-89.
Kozak, N., \& Açıköz, Z. (2015). 7.Akademik Turizm Eğitimi Arama Konferansl "Gastronomi Eğitimi Arama Konferansı" Sonuç Raporu. İstanbul: Aktif Matbaa.

Kurnaz, A. (2011). Yiyecek İçecek Isşletmelerinde Hizmet Kalitesinin Ölçümü: Marmaris Örneği. Yüksek Lisans Tezi. Muğla: Muğla Üniversitesi.

Le Cordon Bleu (2016). Our story. (Erişim: 10.06.2016), https://www.cordonbleu.edu/home/en

Memiş Kocaman, E. (2015). Yiyecek ve İçecek İşletmeciliği Eğitiminin Öğrencilerin Gıda Güvenliği Bilgi Düzeyine Etkisi. Kastamonu Ĕgitim Dergisi, 23(1), 269-280

Nişantaşı Üniversitesi. (2016). Bölüm Hakkında. (Erişim: 09.06.2016),

http://stf.nisantasi.edu.tr/Bolumler/gastronomi-vemutfak-sanatlari.html

ÖSYM (2017). 2017 Öğrenci Seçme ve Yerleştirme Sistemi (ÖSYS) Yükseköğretim Programlarl ve Kontenjanlarl Kılavuzu. (Erişim: 04.11.2017), http://dokuman.osym.gov.tr/pdfdokuman/2017/OSYS/L YS/KONTENJANKILAVUZ18072017.pdf

Özdemir, B. (2010). Dışarıda Yemek Yeme Olgusu: Kuramsal Bir Model Önerisi. Anatolia: Turizm Araştırmaları Dergisi, 21(2), 218-232.

Pavesic, D. V. (1993). Hospitality Education 2005: Curricular and Programmatic Trends. Hospitality Research Journal,17(1), 285-294.

Pitte, J. R. (2002). French Gastronomy: The History and Geography of a Passion. New York: Columbia University Press.

Sandıkçı, M., \& Çelik, S. (2007). Füzyon Mutfak Uygulamaları ve Müşteri Memnuniyeti Açısından Önemi. İçinde: I. Ulusal Gastronomi Sempozyumu ve Sanatsal Etkinlikler (ss. 41-54). Antalya: Akdeniz Üniversitesi Alanya İşletme Fakültesi.

Santich, B. (2004). The Study of Gastronomy and Its Relevance to Hospitality Education and Training. International Journal of Hospitality Management, 23(1), $15-24$.

Santich, B. (2007). The Study of Gastronomy: A Catalyst Cultural Understanding. The International Journal of the Humanities, 5(6), 53-58.

Sevim, B., \& Görkem, O. (2015). Gastronomi ve Aşçılık Programlarında Gıda Güvenliği Donanım Altyapısının Değerlendirilmesi. Uluslararası Alanya İşletme Fakültesi Dergisi, 7(1), 59-67.

Tayfun, A., \& Tokmak, C. (2007). Tüketicilerin Türk Usulü Fastfood Tercih Etme Sebepleri Üzerine Bir Araştırma. Elektronik Sosyal Bilimler Dergisi, 22(22), 169-183.

TDK (Türk Dil Kurumu). (2017). Büyük Türkçe Sözlük. (Erişim Tarihi: 17.10.2017), http://tdk.gov.tr/index.php?option=com_bts\&view=bts

Universita degli studi di Scienze Gastronomiche (2017). Three Year Undergraduate Degree. (Erişim Tarihi: 07.07.2017), https://www.unisg.it/en/programsadmissions/three-year-undergraduate-degree/ 
Universitat de Valencia (2017). Degree in Gastronomic
Sciences.
(Erişim
Tarihi:
08.07.2017),

https:/www.uv.es/uvweb/pharmacy/en/undergraduate-

degree-studies/degree-programmes-

offered/degrees/degree-gastronomic-sciences-

1285852134509/Titulacio.html?id=1285937583385\&pl

antilla=Farmacia/Page/TPGDetaill

Vega, C., \& Ubbink, J. (2008). Molecular Gastronomy: A

Food Fad or Science Supporting Innovative Cuisine?, Trends in Food Science \& Technology, 19(7), 372-382.

Zengin, B., Uyar, H., \& Erkol, G. (2015). Gastronomi Turizmi Üzerine Kavramsal Bir İnceleme. İçinde: Ulusal Turizm Kongresi (ss. 511-524). Ankara: Gazi Üniversitesi.

Zoran, A., \& Coelho, M. (2011). Cornucopia: The Concept of Digital Gastronomy. Leonardo,44(5), 425-431. 